\title{
Intramolecular Asymmetric Desymmetrization via Copper Catalysis
}<smiles>[R]C(=N)C(=O)OC(CN)CN</smiles>

Selected examples:

$$
\text { (trifluoromethyl)phenyl]borate] }
$$<smiles>NC[C@H]1CN=C(c2ccccc2)C(=O)O1</smiles>

$96 \%$ yield, $89 \%$ ee $(41 \mathrm{~h})$<smiles>NC[C@H]1CN=C(c2cccc(Br)c2)C(=O)O1</smiles>

$99 \%$ yield, $91 \%$ ee $(53 \mathrm{~h})$<smiles>COc1ccc(C2=NCC(CN)OC2=O)cc1OC</smiles><smiles>NCC1CN=C(c2ccc(F)cc2)C(=O)O1</smiles>
$98 \%$ yield, $90 \%$ ee (18 h)<smiles>NC[C@H]1CN=C(c2ccc(Br)cc2)C(=O)O1</smiles>

$89 \%$ yield, $90 \%$ ee (31 h)<smiles>COc1ccc(C2=NCC(CN)OC2=O)cc1Br</smiles><smiles>NC[C@H]1CN=C(c2ccc(Cl)c(Cl)c2)C(=O)O1</smiles>

$97 \%$ yield, $93 \%$ ee (72 h)<smiles>COc1ccccc1C1=NC[C@H](CN)OC1=O</smiles>

$99 \%$ yield, $58 \%$ ee (43 h)<smiles>NC[C@H]1CN=C(c2ccc3ccccc3c2)C(=O)O1</smiles>

$98 \%$ yield, $91 \%$ ee (25 h)
Significance: Hydroxy- and amino-functionalized C3-fragments play a pivotal role as synthetic intermediates. Whereas enantioselective desymmetrization of diols and glycerol were developed to provide hydroxyl-containing C3-fragments, the corresponding preparation of amino-containing C3-fragments has been rarely documented. Herein, Gu and co-workers present the asymmetric desymmetrization of 1,3-diazido-2-propanols catalyzed by copper-PhBox.
Comment: The title transformation is enabled in an enantioselective fashion by $\mathrm{CuPF}_{6}(\mathrm{MeCN})_{4}$ in the presence of $(S, S)$-PhBox and NaBARF with the larger and non-coordinating $\mathrm{BARF}^{-}$anion. The new method provides reliable access to enantioenriched azido-substituted 5,6-dihydro-1,4-oxazin-2-ones, which can be further converted into useful $\mathrm{N}$-containing scaffolds. 